\title{
ANALYSIS OF PHYSICAL PROPERTIES AND COMPRESSIBILITY OF AVIAN EGGSHELL NANOPOWDERS IN SOLID STATE REACTION
}

\author{
Poppy Puspitasari $\bowtie$ \\ Departement of Mechanical Engineering \\ Center of Advanced Materials and Renewable Energy ${ }^{l}$ \\ poppy@um.ac.id \\ Muhammad Asrorul Iftiharsa \\ Departement of Mechanical Engineering ${ }^{l}$ \\ Herin Fikri Naufal Zhorifah \\ Departement of Mechanical Engineering ${ }^{I}$ \\ Rara Warih Gayatri \\ Public Health Department ${ }^{1}$ \\ ${ }^{1}$ State University of Malang \\ 5 Semarang str., Malang, East Java, Indonesia, 65145
}

$\checkmark$ Corresponding author

\begin{abstract}
Eggshell is bioceramic material that produces by avian that commonly contains of $94 \%$ calcium carbonate, $1 \%$ magnesium carbonate, $1 \%$ calcium phosphate, and $4 \%$ other organic element. This study proposed to investigate the synthesis and characterization of avian eggshell powders. The avian eggshell that used in this study involved chicken, duck, and quail eggshells. The characterization of avian eggshell nanopowder for reducing their grain size from micro to nano involved ball milling process (solid state reaction) with the variation of milling times (3, 5, and 7 hours) and sintering temperature at $1000{ }^{\circ} \mathrm{C}$ for 2 hours. X-Ray Diffraction (XRD) test presented the phase characterization of quail eggshell nanopowder which ball-milled for 7 hours, obtained the smallest crystallite size at $19.2 \mathrm{~nm}$. Scanning Electron Microscopy (SEM) test presented the morphological analysis that showed changes in grain size and shape of each variety of the avian eggshell such as spherical, oval, wormlike, cubical, triangular, and some irregular grains. Energy Dispersive X-Ray (EDX) test presented the compound in avian eggshell powders that showed Ca and O level were the highest, while $\mathrm{C}$ was the lowest level. Fourier Transform Infrared (FTIR) test presented the possibility of the functional group of the avian eggshell powders that showed $\mathrm{Ca}-\mathrm{O}, \mathrm{Ca}=\mathrm{O}$ groups, $\mathrm{CaCO}_{3}$, asymmetric $\mathrm{C}-\mathrm{O},-\mathrm{CO}_{3}$, amide, $\mathrm{C}=\mathrm{O},-\mathrm{OH}$, alkyl $\mathrm{CH}$, and C-H. While compressibility shown the increase along with the decrease of crystallite and particles size in cubical grain. The highest compression ratio is $67.75 \%$ for chicken eggshell nano powder with 5 hours milling time at $2000 \mathrm{kgf}$ of compression loading.

Keywords: Phase identification, compressibility, avian eggshell, solid state reaction, ball milling, milling time, morphology, molecular bonding, bioceramic, grain shape.
\end{abstract}

DOI: $10.21303 / 2461-4262.2021 .001670$

\section{Introduction}

Avian eggshells are bioceramic materials that produced by avian, functioning to protect the egg from mechanical damage [1]. The eggshells are complex permeable bioceramic materials and very structured with large mixing both organic and non-organic phases that showed simple overlap between non-calcified and calcified eggshell membrane [2]. Eggshell contains about $8.5-11 \%$ total mass of the egg, with thickness about $355 \mu \mathrm{m}[3,4]$. Generally, eggshell arranged by $94 \%$ calcium carbonate $\left(\mathrm{CaCO}_{3}\right), 1 \%$ magnesium carbonate $\left(\mathrm{MgCO}_{3}\right), 1 \%$ calcium phosphate $\left(\mathrm{Ca}_{3}\left(\mathrm{PO}_{4}\right)_{2}\right)$, and $4 \%$ organic matter, usually protein, collagen, and sulfated polysaccharides [3-6].

Utilizations of eggshell biological wastes are highly recommended in our society because of environmental and economic reasons. It is known that eggshell wastes contain valuable organic and inorganic component which can be used in commercial product with new value in this waste materials [5]. Especially in Indonesia, that has abundant eggshell wastes. This is because the amount of egg consumption by the Indonesian people is quite high, besides that the shell waste is also 
produced from the remnants of the hatchery in the chicken nursery industry [7]. Another reason is because the egg production in Indonesia increases each year, for example, the production of quail egg in 2013 was 18,936 tons then increases to 25,272 tons in 2017 [8].

Eggshells itself have been used in various research such as catalyst for biodiesel and used as a binder [9]. The eggshell also used as filler and precursor for cement mortar in making of gypsum, even used as drug delivery in medical sector [10,11]. For other applications, eggshells also used as reinforcement at cast metal alloy, even used as basic material to make hydroxyapatite which can be used as an implant material for bone and used as tooth filler $[7,12,13]$. In the form of $\mathrm{CaCO}_{3}$, many application has been discussed. One of them is the application for alkali-activated aluminosilicate binders [14]. It was revealed that the addition of $\mathrm{CaCO}_{3}$ intensified the nano-structured formation processes in the direction of formation of $\mathrm{Na}-\mathrm{Ca}$ zeolite-like phases and shortening the required time for cement stone to gain water resistance in normal conditions [15].

Based on these data, the objective of this research is to utilize eggshell waste into $\mathrm{CaCO}_{3}$ powder in an easy and inexpensive way that can later be used in various applications. The synthesis that was carried out to obtain $\mathrm{CaCO}_{3}$ from eggshells was by ball-milling process, therefore to get the best results, this study used variations in milling time and carried out characterization in the form of phase identification, morphology, functional groups, and compressibility values. The results of this characterization will be useful for the application of $\mathrm{CaCO}_{3}$ as a tooth filler in dental implants.

\section{Materials and methods}

In this research the specimen that used are variation of dried avian eggshells which includes chicken, duck, and quail eggshell. The synthesis of avian eggshells done with ball mill method using planetary ball mill (MTI QM-3SP2), which intend to produce particles in nano-sized by mixing $300 \mathrm{~g}$ micro-sized of eggshell with $100 \mathrm{ml}$ of acetone, to obtain the optimum result of final particle size [16]. The mixing was carried out with the variation of milling time, i. e. 3, 5, and 7 hours for each variety of the eggshell. After ball mill process, drying was done at temperature $110{ }^{\circ} \mathrm{C}$ for 1 hour [15]. The next process is crushing for 1 hour [8]. After crushing, sintering process has been done at temperature $1000^{\circ} \mathrm{C}$ for 2 hours [7]. After sintering, do crushing for 1 hour [8]. The characterization process aims to identify phase, morphology, elemental composition, and functional groups using XRD (PanAnalytical E'xpert Pro), SEM-EDX (FEI Inspect-S50), and FTIR (Shimadzu IRPrestige21). For compressibility test, it used cold pressing by using universal testing machine (ILE IL-904) with load of $1000 \mathrm{kgf}$ and $2000 \mathrm{kgf}$ for 90 seconds [17].

Fig. 1 shows the samples after ball milling process for 7 hours that consist of sintering and non-sintering powder.

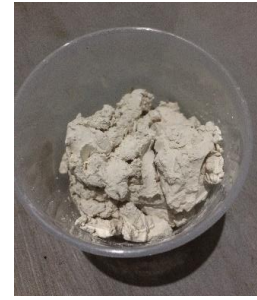

$a$

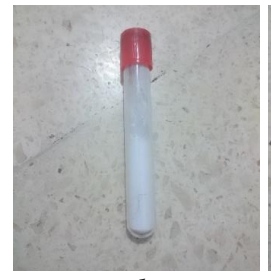

$d$

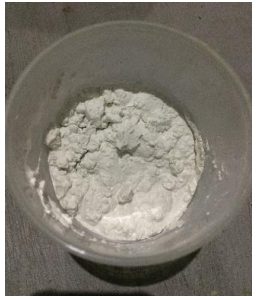

$b$

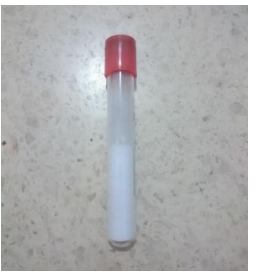

$e$

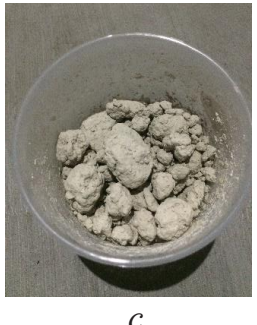

$c$

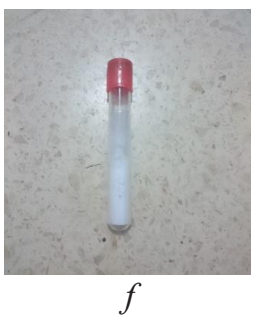

Fig. 1. Avian eggshells after ball mill process: $a$ - chicken eggshell non-sintering;

$b$ - duck eggshell non-sintering; $c$ - quail eggshell non-sintering; $d$ - chicken eggshell after sintering; $e$ - duck eggshell after sintering; $f$ - quail eggshell after sintering 
Fig. 1, $\boldsymbol{a}, \boldsymbol{b}$, and c are the chicken, duck, and quail eggshell without sintering process and crushed for 1 hours, respectively. Fig. 1, $\boldsymbol{d}, \boldsymbol{e}, \boldsymbol{f}$ are the chicken, duck, and quail eggshell with sintering process at $1000{ }^{\circ} \mathrm{C}$ for 2 hours in environmental condition and crushed for 1 hours.

\section{Results}

Naming of samples in this discussion using (CES) for chicken eggshell, (DES) for duck eggshell, and (QES) for quail eggshell with (M3H) for 3 hours of milling time, $(\mathrm{M} 5 \mathrm{H})$ for 5 hours of milling time, and $(\mathrm{M} 7 \mathrm{H})$ for 7 hours of milling time.

\section{1. Phase Identification}

The results of XRD test were shown in Fig. 2. Intensity, FWHM, d-spacing, and crystallite size are shown in Table 1. The crystallite size was calculated using Scherrer (1) as $[8,15]$ :

$$
d=\frac{k \cdot \lambda}{\beta \cos } \text {. }
$$

Where $d$ is the diameter of crystallite, $K$ is the constant $(0.89-0.9), \lambda$ is the wavelength (1.5406 $\AA$ ), and $\beta$ is Full-Width Half Maximum (FWHM).

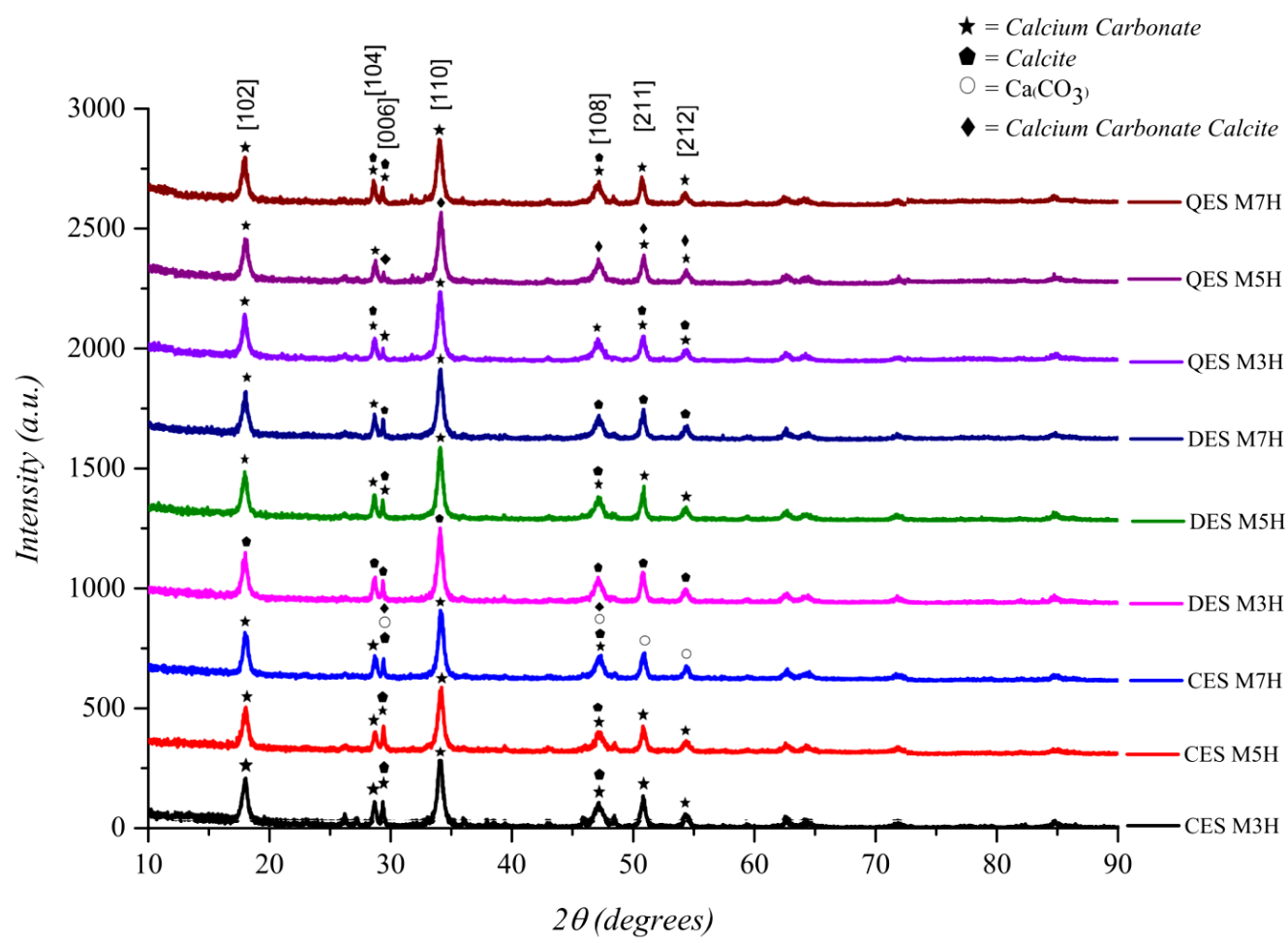

Fig. 2. Diffractogram graph of avian eggshell nanopowders

XRD test results were analyzed using Match! software (v3.8.0.137) with crystallography reference database used (COD-Inorg REV218120 2019.09.10). The results of XRD test shown that all samples have several peaks, namely [102], [104], [006], [110], [108], [211], and [212] which appropriate with trigonal phase. The highest peak is positioned at $34,1^{\circ} 2 \mathrm{Th}$. The existence of peak indicated the presence of $\mathrm{CaCO}_{3}$, with the form of $\mathrm{Ca}\left(\mathrm{CO}_{3}\right)$ which has crystal system of monoclinic, calcium carbonate calcite which has crystal system of rhombohedral, and calcium carbonate and calcite which has crystal system of trigonal (hexagonal axes).

Based on Fig. 2, it can be seen visually that the XRD results have similiar pattern. However, Table 1 shows that there is a difference in intensity and FWHM. Also, based on Table 1, it can be seen that the intensity has a correlation with the crystallite size. The higher the intensity, the larger crystallite size originating from the increase of FWHM [2]. The smallest crystallite 
size which counted is $19.2 \mathrm{~nm}$ at quail eggshell nanopowder with 7 hours of milling time, and the largest crystallite size which counted is $30.2 \mathrm{~nm}$ at duck eggshell nanopowder with 3 hours of milling time and quail eggshell nanopowder with 5 hours of milling time.

Table 1

Intensity, FWHM, d-spacing, and crystallite size of avian eggshell nanopowders

\begin{tabular}{|c|c|c|c|c|}
\hline \multirow{2}{*}{ Samples } & \multicolumn{4}{|c|}{ X-Ray Diffraction (correspond to peak [110]) } \\
\hline & Intensity (cts) & FWHM (rad) & d-spacing $(\AA)$ & Crystallite size (nm) \\
\hline CES M3H & 260.02 & 0.006181956 & 2.62657 & 23.5 \\
\hline CES M5H & 238.64 & 0.006869616 & 2.62356 & 21.1 \\
\hline CES M7H & 255.92 & 0.006181956 & 2.62236 & 23.5 \\
\hline DES M3H & 285.00 & 0.004808382 & 2.62849 & 30.2 \\
\hline DES M5H & 274.76 & 0.005496042 & 2.62877 & 26.4 \\
\hline DES M7H & 260.26 & 0.005496042 & 2.62810 & 26.4 \\
\hline QES M3H & 275.07 & 0.006181956 & 2.62807 & 23.5 \\
\hline QES M5H & 277.43 & 0.004808382 & 2.62466 & 30.2 \\
\hline QES M7H & 262.90 & 0.007557276 & 2.63164 & 19.2 \\
\hline
\end{tabular}

The correlation between milling time and crystallite size was shown in Fig. 3, while the correlation between type of avian eggshell powder and crystallite size was shown in Fig. 4.

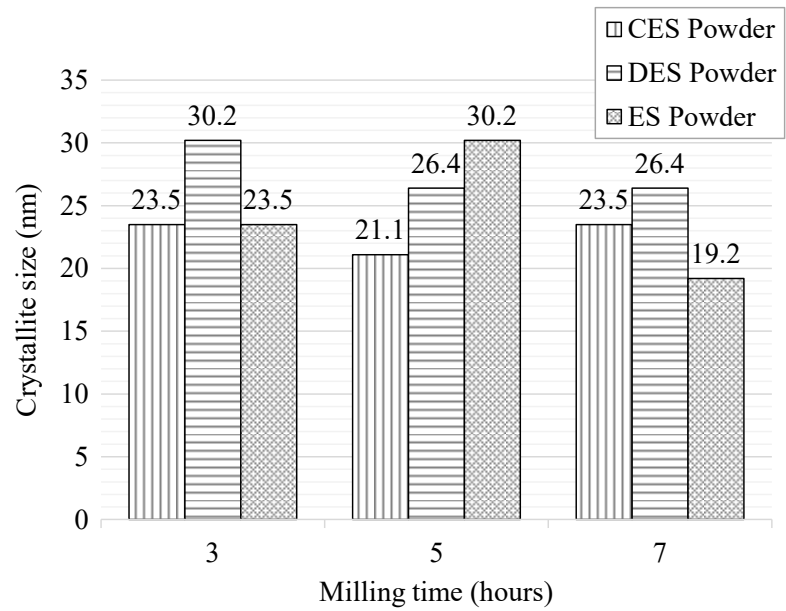

Fig. 3. Correlation between milling time and crystallite size

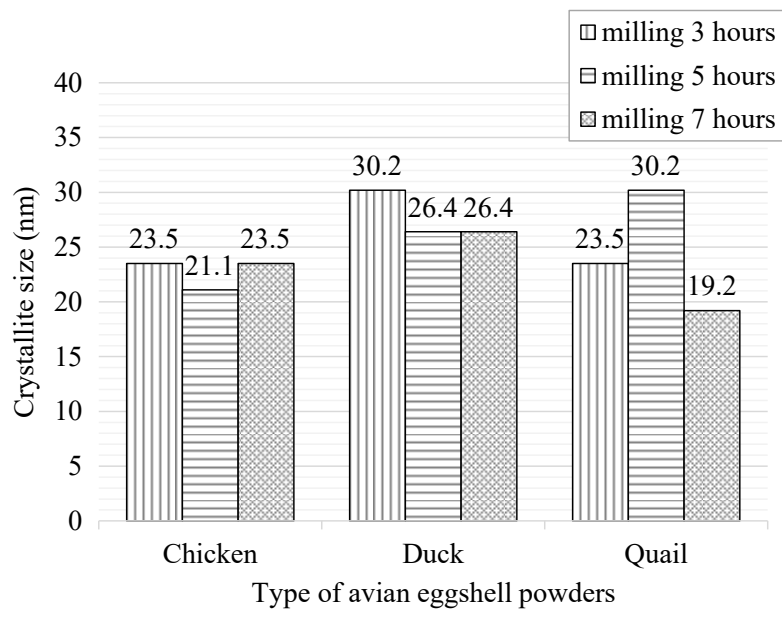

Fig. 4. Correlation between type of avian eggshell powder and crystallite size 


\section{2. Morphological Characterization}

The morphology of avian eggshell was observed by using SEM [2-4]. The SEM results of avian eggshell powders with variation of milling times, shown in Fig. 5.

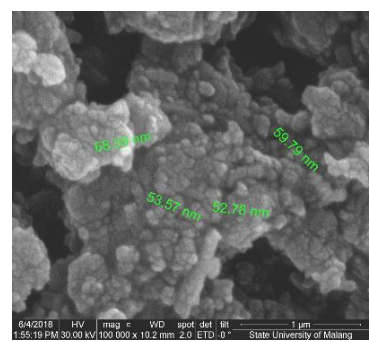

$a$

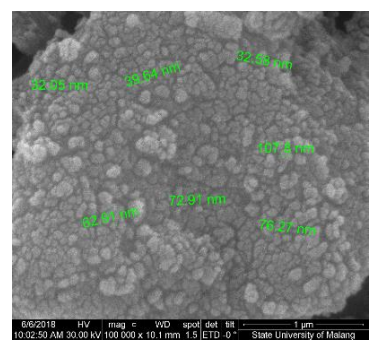

$d$

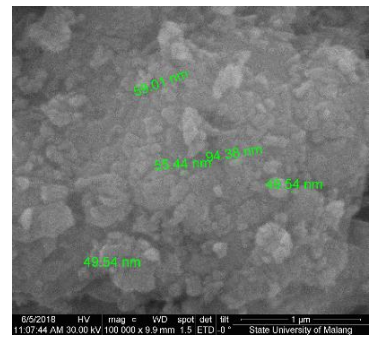

$g$

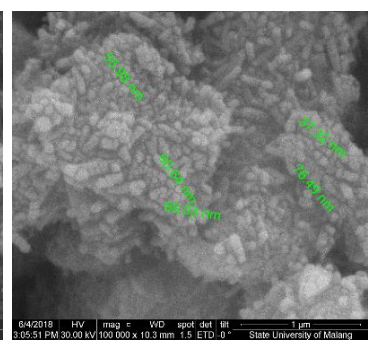

$b$

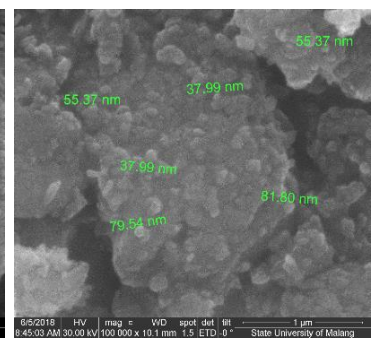

$e$

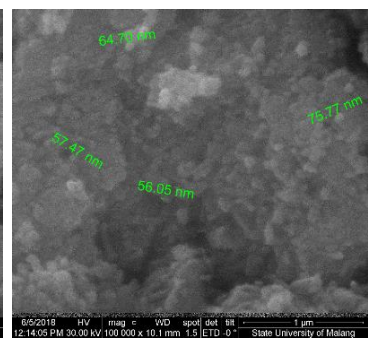

$h$

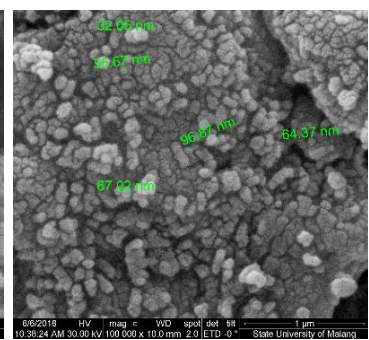

c

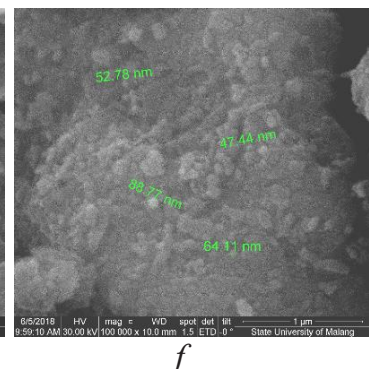

$f$

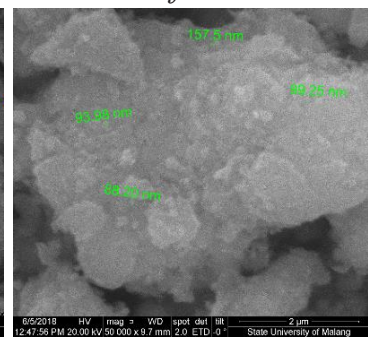

$i$

Fig. 5. Morphology of avian eggshell nanopowders:

$a$ - CES M3H; $b$ - CES M5H; $c$ - CES M7H; $d$ - DES M3H; $e$ - DES M5H; $f$ - DES M7H; $g-$ QES M3H; $h-$ QES M5H; $i-$ QES M7H

Fig. 5 shows the morphology of avian eggshell nanopowders with magnification of 100000 times. Fig. 5, $\boldsymbol{a}$ shows the morphology of chicken eggshell nanopowder with 3 hours of milling time was spherical with few of oval with the smallest size was $52.78 \mathrm{~nm}$ and the largest size was 68.59 nm. Fig. 5, $\boldsymbol{b}$ shows the morphology of chicken eggshell nanopowder with 5 hours of milling time was have the form of wormlike with the smallest size was $37.32 \mathrm{~nm}$ and the largest size was 76.49 nm. Fig. 5, $c$ shows the morphology of chicken eggshell nanopowder with 7 hours of milling time was roundness and few of oval with the smallest size was $32.05 \mathrm{~nm}$ and the largest size was $96.87 \mathrm{~nm}$.

Fig. 5, $\boldsymbol{d}$ shows the morphology of duck eggshell nanopowder with 3 hours of milling time was spherical with few of oval with the smallest size was $32.05 \mathrm{~nm}$ and the largest size was $107.8 \mathrm{~nm}$. Fig. 5, e shows the morphology of duck eggshell nanopowder with 5 hours of milling time was cubical with the smallest size was $37.99 \mathrm{~nm}$ and the largest size was $81.80 \mathrm{~nm}$. Fig. 5, $\boldsymbol{f}$ shows the morphology of duck eggshell nanopowder with 7 hours of milling time was spherical and few of irragular with the smallest size was $47.44 \mathrm{~nm}$ and the largest size was $88.77 \mathrm{~nm}$.

Fig. 5, $\boldsymbol{g}$ shows the morphology of quail eggshell nanopowder with 3 hours of milling time was spherical, with few of cubical and triangular with the smallest size was $49.54 \mathrm{~nm}$ and the largest size was $94.38 \mathrm{~nm}$. Fig. 5, $\boldsymbol{h}$ shows the morphology of quail eggshell nanopowder with 5 hours of milling time was spherical and few of oval with the smallest size was $56.05 \mathrm{~nm}$ and the largest size was $75.77 \mathrm{~nm}$. Fig. 5, $\boldsymbol{i}$ shows the morphology of quail eggshell nanopowder with 
7 hours of milling time was cubical, spherical, and few of triangular with the smallest size was $88.20 \mathrm{~nm}$ and the largest size was $157.5 \mathrm{~nm}$.

In Fig. $\mathbf{5}, \boldsymbol{a}-\boldsymbol{d}$, the uniformity in the structure of grains on the surface showed that agglomeration was the sediment particles on the membrane of eggshell nanopowders grains [2]. While in Figure Fig. 5, $\boldsymbol{e}-\boldsymbol{i}$, the uniformity in the structure of grains on the surface showed that agglomeration was occurred as particles deposited on the membrane of eggshell nanopowders grains [2]. There is no significant change in the particles size which cause by kinetic energy used in milling process that causing the reduction of particle size can be achieved by longer milling time [5].

\section{3. Functional Groups Characterization}

The functional group of avian eggshell nanopowders has been observed by using FTIR test. The results of FTIR test were showed in Fig. 6.

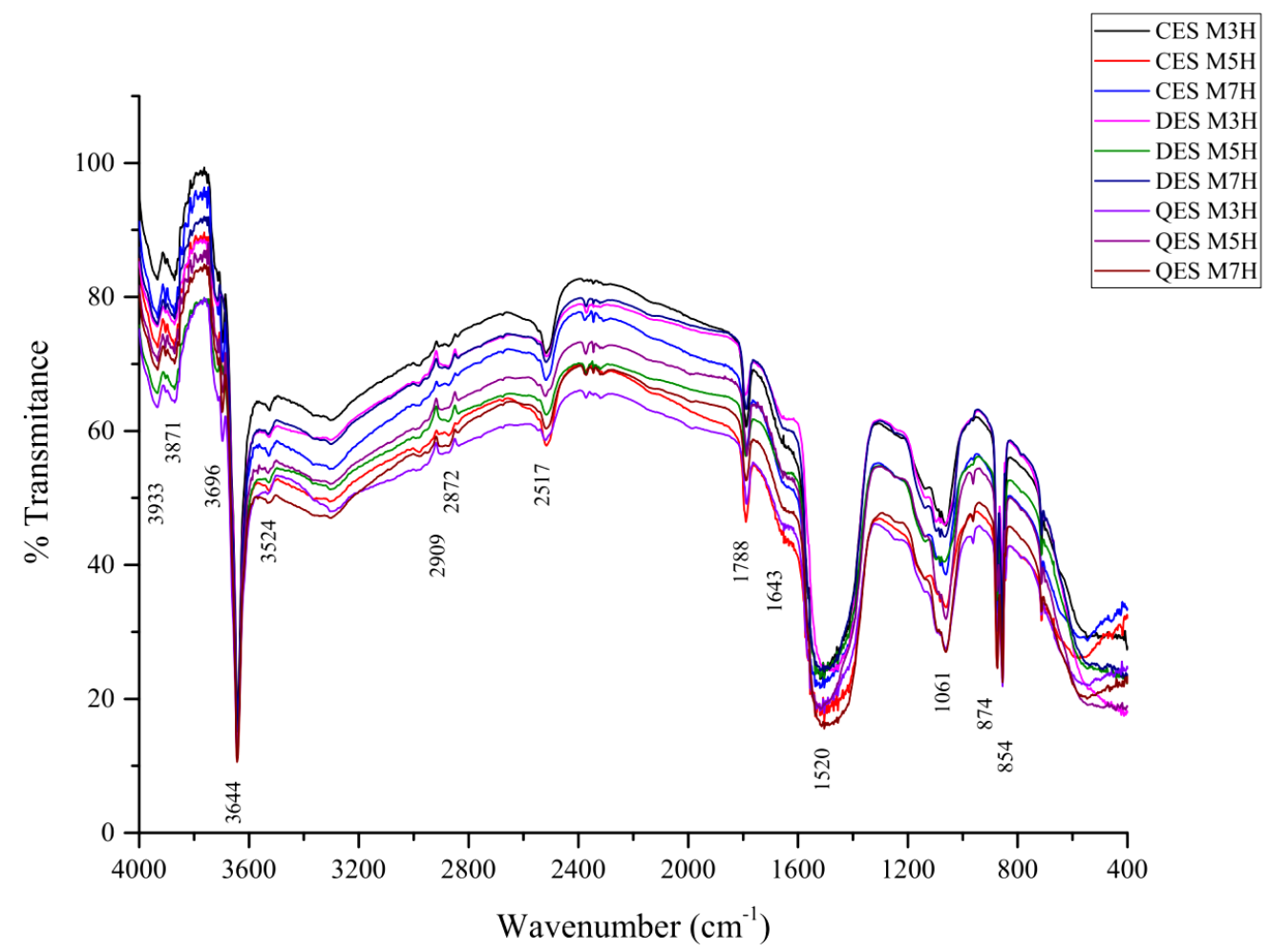

Fig. 6. FTIR spectra of avian eggshell nanopowders

Fig. 6 shows that the strong peaks were observed at the bands 3644 and $1520 \mathrm{~cm}^{-1}$. Bands at 3644 and $2517 \mathrm{~cm}^{-1}$ possibly indicate to the presence of hydroxyl alcohol group (-OH) stretching during adsorption of water by $\mathrm{CaO}$ and acidic hydrogen group (-OH) stretching, respectively $[8,18]$. Band at $1520 \mathrm{~cm}^{-1}$ can be related to the presence of carbonate mineral $\left(-\mathrm{CO}_{3}\right)$ in the matrix of eggshell powders $[18,19]$. Bands at 854 and $874 \mathrm{~cm}^{-1}$ possibly related to in-plane and out-plane deformations, which indicate to the presence of calcium carbonate $\left(\mathrm{CaCO}_{3}\right)[8,18,20]$. Bands at 874 and $1520 \mathrm{~cm}^{-1}$ also related with asymmetric C-O with carbonate group vibration [8]. Bands at 2909 and $2872 \mathrm{~cm}^{-1}$ represent $\mathrm{C}-\mathrm{H}$ vibration and assign to alkyl $\mathrm{CH}$, which indicating the existence of organic layers, built from amino acids, in the eggshells $[8,18]$. Bands at 1788 and $1643 \mathrm{~cm}^{-1}$ correspond with $\mathrm{C}=\mathrm{O}$ and carbonyl group stretching (amide), respectively [18]. Bands at $500-580 \mathrm{~cm}^{-1}$ and $586 \mathrm{~cm}^{-1}$ shows the presence of $\mathrm{Ca}-\mathrm{O}$ bond and $\mathrm{Ca}=\mathrm{O}$ group, respectively $[8,20]$. The differences of FTIR spectra of avian eggshell powders can be occur because of chemical treatment like oxidation, addition, and substitution that would effect the chemical nature of membrane top layer [21]. It also known that the final stoichiometry depends on the control and monitoring of the milling conditions [6]. 


\section{4. Analysis of compressibility}

Compressibility and compression ratio has been calculated using (2), (3) [22, 23], respectively. The results have been sorted by the grain shapes that found on each sample and has been shown in Table 3. Fig. 7-10 has showed the correlations between physical properties and compressibility of the samples.

$$
\begin{gathered}
\rho_{p}=\frac{m}{V}, \\
C R=\frac{h_{0}-h_{p}}{h_{0}} \cdot 100 \%,
\end{gathered}
$$

where $\rho_{p}$ is the compressibility $\left(\mathrm{g} / \mathrm{cm}^{3}\right) ; m$ is compact mass $(\mathrm{g}) ; V$ is compact volume $\left(\mathrm{cm}^{3}\right)$; $C R$ is compression ratio $(\%) ; h_{0}$ is height at zero pressure $(\mathrm{cm}), h_{p}$ is compact height $(\mathrm{cm})$.

Table 3

Crystallite sizes, particle sizes, compression ratio, and compressibility of eggshell nanopowders

\begin{tabular}{lccccccc}
\hline \multirow{2}{*}{$\begin{array}{c}\text { Grain } \\
\text { shapes }\end{array}$} & \multirow{2}{*}{ Samples } & $\begin{array}{c}\text { Crystallite size } \\
(\mathbf{n m})\end{array}$ & $\begin{array}{c}\text { Particle } \\
\text { sizes }(\mathbf{n m})\end{array}$ & $\mathbf{1 0 0 0} \mathbf{~ k g f}$ & $\mathbf{2 0 0 0} \mathbf{~ k g f}$ & $\mathbf{1 0 0 0} \mathbf{~ k g f}$ & $\mathbf{2 0 0 0} \mathbf{~ k g f}$ \\
\hline Spherical & QES M5H & 30.2 & 56.05 & 59.50 & 61.00 & 1.56 & 1.60 \\
Oval & DES M3H & 30.2 & 32.05 & 63.25 & 63.00 & 1.64 & 1.67 \\
& DES M7H & 26.4 & 47.44 & 61.25 & 67.00 & 1.64 & 1.76 \\
& CES M3H & 23.5 & 52.78 & 64.00 & 67.50 & 1.56 & 1.70 \\
Cubical & DES M5H & 26.4 & 37.99 & 58.00 & 64.00 & 1.63 & 1.76 \\
Triangular & QES M3H & 23.5 & 49.54 & 60.00 & 61.50 & 1.57 & 1.65 \\
Spherical & CES M7H & 23.5 & 32.05 & 60.75 & 61.25 & 1.56 & 1.66 \\
Oval & QES M7H & 19.2 & 88.2 & 53.75 & 60.75 & 1.56 & 1.61 \\
Wormlike & CES M5H & 21.1 & 37.32 & 63.50 & 67.75 & 1.63 & 1.71
\end{tabular}

Fig. 7, 8 show that the compressibility and compression ratio of samples with spherical and oval grain shapes have increase on both 1000 and $2000 \mathrm{kgf}$ of load. It is because of the increasing of compressibility and compression ratio along with the decreasing of crystallite and particle sizes [23, 24]. While Fig. 9, 10 show that the compressibility and compression ratio in samples with cubical, triangular, spherical and oval grain shapes slightly decrease on both 1000 and $2000 \mathrm{kgf}$ of load, due to morphology such as particle sizes and grain shapes take effect on compressibility [25]. It is because the irregular grain shapes of grain are more difficult to compact than spherical grain shapes, due to it can make it easier to shear deformations to happen [26]. In this reasearch, the milling times does not have significant effect to the compressibility.

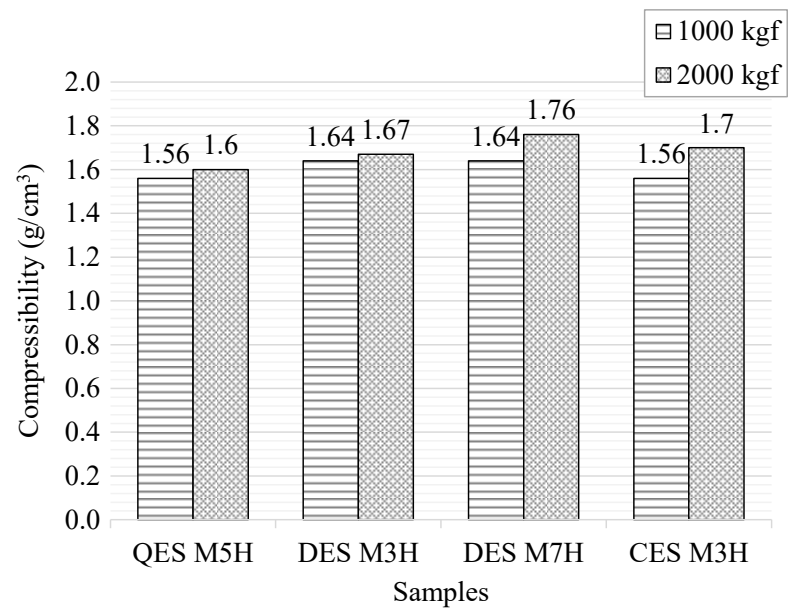

Fig. 7. Compressibility in spherical and oval grain shapes 


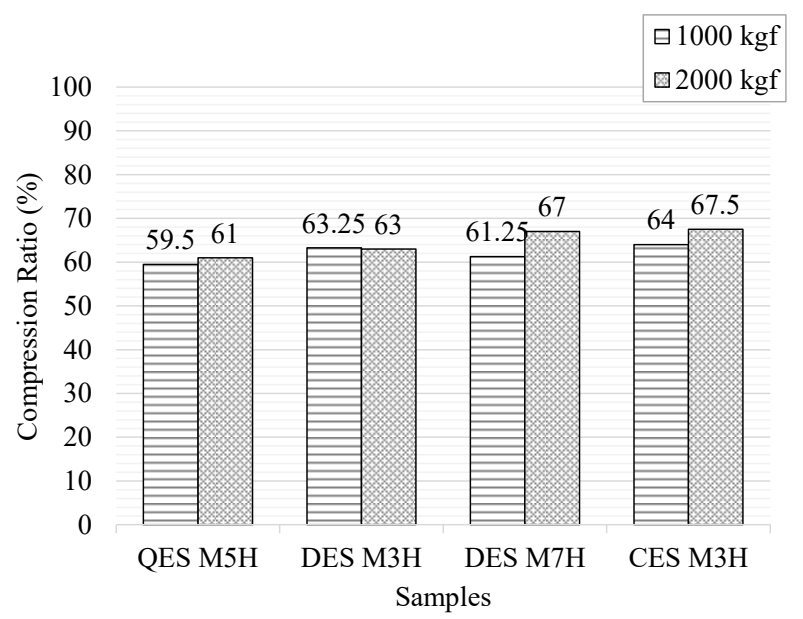

Fig. 8. Compression ratio in spherical and oval grain shapes

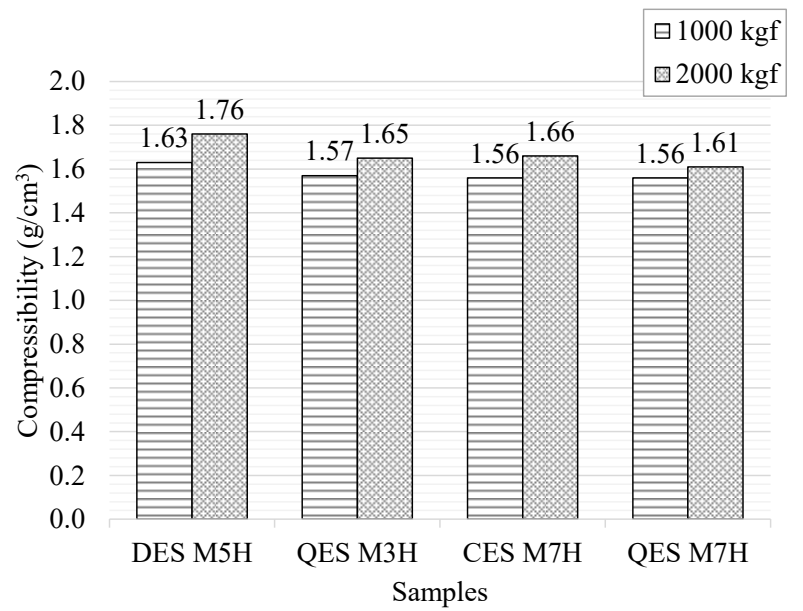

Fig. 9. Compressibility in cubical, triangular, spherical, and oval grain shapes

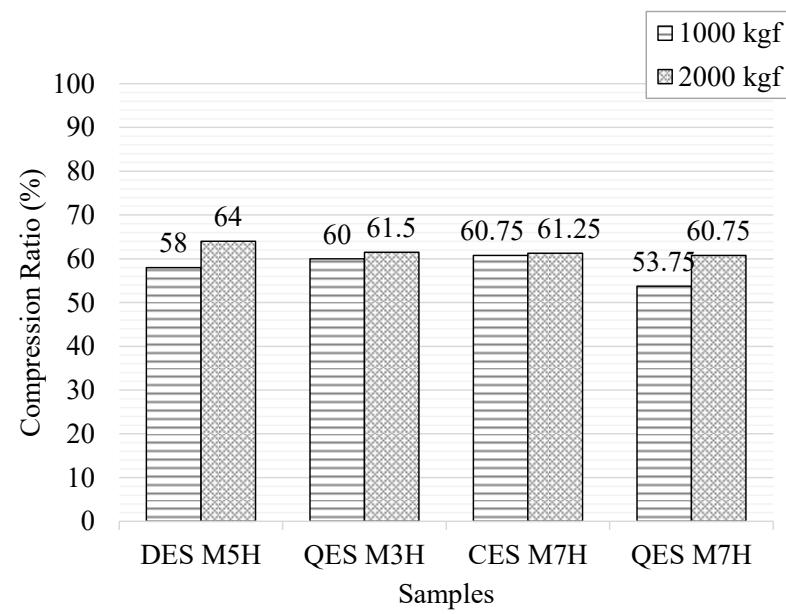

Fig. 10. Compression ratio in cubical, triangular, spherical, and oval grain shapes

\section{Discussion of experimental results}

The results of data analysis showed that the crystallite size with a longer milling time had a smaller size. Meanwhile, larger crystallite sizes can be due to agglomeration and also the sintering process which can cause larger grain sizes [7]. This is because at the same time, the grain 
size increases as the temperature increases, it approaching $1 \mu \mathrm{m}$ at $1000{ }^{\circ} \mathrm{C}$ (1273 K) [27]. The phases found in this study are calcium carbonate and calcite which have a trigonal crystal system (hexagonal axes), $\mathrm{Ca}\left(\mathrm{CO}_{3}\right)$ which has a monoclinic crystal system, and calcium carbonate calcite which has a rhombohedral crystal system. The crystalline phase in this study did not change significantly, it was indicated by all the phases found that were still included in the carbonate mineral. This means that the milling process cannot change the structure of the test specimen. Theoretically, the energy supplied from this process cannot overcome the breakdown of the structure [15].

Based on SEM result, it is also known that the dominant grain diameter size of the powdered poultry egg shell with the variation of the milling time is on average below $100 \mathrm{~nm}$ which makes it classified as a nanopowder. In the test specimens of eggshell powder, it can be seen that the particle size is not much different, it could be due to the milling time which is not too different. This is because the kinetic energy used in the milling process which causes a reduction in particle size can be obtained with a longer milling time [28].

Differences in the FTIR spectra of eggshell powder can occur due to chemical treatments such as oxidation, addition, and substitution which can result in chemical properties of the top layer of the membrane [21]. It is also known that the final stoichiometry depends on controlling and monitoring the milling conditions [28].

This research offers a synthetic method for processing large amounts of eggshell waste using a solid state reaction. When compared to other synthesis methods, such as sol-gel and coprecipitation, the solid state reaction method is a method that can produce a large number of products. The drawback of this method is that the results obtained have a morphology that is not uniform and tends to agglomerate, therefore, to achieve the uniform size of nanoparticles it is necessary to carry out further synthesis or by using high energy ball milling process. The correlation between physical properties and compressibility is influenced by the grain shape and the size of the crystal or particle. Meanwhile, in this research, it was shown that the milling time did not have a significant effect on grain shape, crystal size, and particle size. This indicates that the milling time used in this study has small effect on the correlation between physical properties and compressibility of poultry eggshell nano powder (chicken, duck, and quail). From this results, $\mathrm{CaCO}_{3}$ derived from eggshell is a good candidate for tooth filler because it has good compressibility for almost all the type of eggshells. From all characterization results, the three types of eggshells have similarities with each other. But if we look more closely, duck eggshells have a more stable character in terms of crystallite size, compressibility, and uniform morphology not to mention about the availability compare to the quail eggshell. This study focused on the use of eggshells as implant material and from this study, the best eggshells were duck eggshells with a milling time variation of 5 hours. From the simulation results in the previous research, $\mathrm{CaCO}_{3}$ from eggshell powder was increase the strength of mastication 40 times and the most important parameter is the crystallite size of $\mathrm{CaCO}_{3}[7,8]$. Other application that related to the implant material is hydroxyapatite (HA) that can be obtain from $\mathrm{CaCO}_{3}$ and natrium phosphate. The biocompatibility and bioactivity properties of HA from eggshell powder has similarities with inorganic components of hard tissue in natural tissue of bones and teeth $[29,30]$.

\section{Conclusion}

Nanopowders of the avian eggshell wastes had been successfully produced by the ball mill process. The smallest crystallite size which counted is $19.2 \mathrm{~nm}$ at quail eggshell nanopowder with 7 hours of milling time, and the largest crystallite size which counted is $30.2 \mathrm{~nm}$ at duck eggshell nanopowder with 3 hours of milling time and quail eggshell nanopowder with 5 hours of milling time. The morphology shows that the major shape of the grains is spherical, but there is no significant change to the grains of avian eggshell nanopowders. The elemental composition represents the dominant element that can be found in avian eggshell nanopowders are calcium $(\mathrm{Ca})$, oxygen $(\mathrm{O})$, and carbon $(\mathrm{C})$. The functional group shows the existence of $\mathrm{CaCO}_{3}, \mathrm{CaO}$, and carbonate mineral contained in avian eggshell nanopowders. While compressibility of avian eggshell nanopowders will increase along with decreasing of crystallite and particle sizes. The grain shapes will take effect of the compressibility because it can effect 
deformations. Based on the results, by knowing the physical properties of the avian eggshell nanopowders, it can be used for multipurpose applications such as material to make hydroxyapatite, tooth filler, catalyst, reinforce, and also become proper material for mass production of $\mathrm{CaCO}_{3}$ and $\mathrm{CaO}$.

\section{Acknowledgement}

The authors would like to thank to Kemenristek/BRIN for Hibah PDUPT lanjutan 2020 for Poppy Puspitasari.

\section{References}

[1] Sun, C., Duan, Z., Qu, L., Zheng, J., Yang, N., Xu, G. (2016). Expression analysis for candidate genes associated with eggshell mechanical property. Journal of Integrative Agriculture, 15 (2), 397-402. doi: https://doi.org/10.1016/s2095-3119(14)60969-2

[2] Hincke, M., Gautron, J., Rodriguez-Navarro, A. B., McKee, M. D. (2011). The eggshell: structure and protective function. Improving the Safety and Quality of Eggs and Egg Products, 151-182. doi: https://doi.org/10.1533/9780857093912.2.151

[3] Aygun, A. (2017). The Eggshell Microbial Activity. Egg Innovations and Strategies for Improvements, 135-144. doi: https:// doi.org/10.1016/b978-0-12-800879-9.00013-5

[4] Fernandes, E. de A., Litz, F. H. (2017). The Eggshell and Its Commercial and Production Importance. Egg Innovations and Strategies for Improvements, 261-270. doi: https://doi.org/10.1016/b978-0-12-800879-9.00025-1

[5] Yew, M. C., Ramli Sulong, N. H., Yew, M. K., Amalina, M. A., Johan, M. R. (2013). The formulation and study of the thermal stability and mechanical properties of an acrylic coating using chicken eggshell as a novel bio-filler. Progress in Organic Coatings, 76 (11), 1549-1555. doi: https://doi.org/10.1016/j.porgcoat.2013.06.011

[6] Saeb, M. R., Rastin, H., Nonahal, M., Paran, S. M. R., Khonakdar, H. A., Puglia, D. (2018). Cure kinetics of epoxy/chicken eggshell biowaste composites: Isothermal calorimetric and chemorheological analyses. Progress in Organic Coatings, 114, 208-215. doi: https://doi.org/10.1016/j.porgcoat.2017.10.018

[7] Zhorifah, H. F. N., Puspitasari, P., Andoko, Tsamroh, D. I., Permanasari, A. A. (2019). Optimization of the mastication strength of hydroxyapatite as an eggshell-based tooth filler. International Conference on Biology and Applied Science (ICOBAS). doi: https://doi.org/10.1063/1.5115686

[8] Supriyanto, N. S. W., Sukarni, Puspitasari, P., Permanasari, A. A. (2019). Synthesis and characterization of $\mathrm{CaO} / \mathrm{CaCO}_{3}$ from quail eggshell waste by solid state reaction process. International Conference on Biology and Applied Science (ICOBAS). doi: https://doi.org/10.1063/1.5115670

[9] Ayodeji, A. A., Modupe, O. E., Rasheed, B., Ayodele, J. M. (2018). Data on CaO and eggshell catalysts used for biodiesel production. Data in Brief, 19, 1466-1473. doi: https://doi.org/10.1016/j.dib.2018.06.028

[10] Pliya, P., Cree, D. (2015). Limestone derived eggshell powder as a replacement in Portland cement mortar. Construction and Building Materials, 95, 1-9. doi: https://doi.org/10.1016/j.conbuildmat.2015.07.103

[11] Jayasree, R., Madhumathi, K., Rana, D., Ramalingam, M., Nankar, R. P., Doble, M., Kumar, T. S. S. (2018). Development of Egg Shell Derived Carbonated Apatite Nanocarrier System for Drug Delivery. Journal of Nanoscience and Nanotechnology, 18 (4), 2318-2324. doi: https://doi.org/10.1166/jnn.2018.14377

[12] Zhu, H., Guo, D., Sun, L., Li, H., Hanaor, D. A. H., Schmidt, F., Xu, K. (2018). Nanostructural insights into the dissolution behavior of Sr-doped hydroxyapatite. Journal of the European Ceramic Society, 38 (16), 5554-5562. doi: https://doi.org/10.1016/ j.jeurceramsoc.2018.07.056

[13] Puspitasari, P., Safarudin, R. A., Sasongko, M. I. N., Achyarsyah, M., Andoko. (2019). Analysis of Mechanical and Physical Properties of Al-Si (Al-Si) Casting Alloys Reinforced with Various Eggshell Nanopowders. IOP Conference Series: Materials Science and Engineering, 515, 012028. doi: https://doi.org/10.1088/1757-899x/515/1/012028

[14] Bodnarova, L., Guzii, S., Hela, R., Krivenko, P., Vozniuk, G. (2018). Nano-Structured Alkaline Aluminosilicate Binder by Carbonate Mineral Addition. Solid State Phenomena, 276, 192-197. doi: https://doi.org/10.4028/www.scientific.net/ssp.276.192

[15] Puspitasari, P., Yuwanda, V., Sukarni, Dika, J. W. (2019). The Properties of Eggshell Powders with the Variation of Sintering Duration. IOP Conference Series: Materials Science and Engineering, 515, 012104. doi: https://oi.org/10.1088/ $1757-899 x / 515 / 1 / 012104$

[16] Nandiyanto, A. B. D., Andika, R., Aziz, M., Riza, L. S. (2018). Working Volume and Milling Time on the Product Size/Morphology, Product Yield, and Electricity Consumption in the Ball-Milling Process of Organic Material. Indonesian Journal of Science and Technology, 3 (2), 82. doi: https://doi.org/10.17509/ijost.v3i2.12752

[17] Qosim, N., Murdanto, P., Puspitasari, P. (2018). Analisis Sifat Fisik dan Kompresibilitas Nanopowder Zinc Oxide (ZnO) sebagai Alternatif Material Amalgam. Jurnal Rekayasa Mesin, 9 (1), 9-14. doi: https://doi.org/10.21776/ub.jrm.2018.009.01.2 
[18] Tizo, M. S., Blanco, L. A. V., Cagas, A. C. Q., Dela Cruz, B. R. B., Encoy, J. C., Gunting, J. V. et. al. (2018). Efficiency of calcium carbonate from eggshells as an adsorbent for cadmium removal in aqueous solution. Sustainable Environment Research, 28 (6), 326-332. doi: https://doi.org/10.1016/j.serj.2018.09.002

[19] Carvalho, J., Araujo, J., Castro, F. (2011). Alternative Low-cost Adsorbent for Water and Wastewater Decontamination Derived from Eggshell Waste: An Overview. Waste and Biomass Valorization, 2 (2), 157-167. doi: https://doi.org/10.1007/s12649-010-9058-y

[20] Choudhary, R., Koppala, S., Swamiappan, S. (2015). Bioactivity studies of calcium magnesium silicate prepared from eggshell waste by sol-gel combustion synthesis. Journal of Asian Ceramic Societies, 3 (2), 173-177. doi: https://doi.org/10.1016/j.jascer.2015.01.002

[21] Mohamed, M. A., Jaafar, J., Ismail, A. F., Othman, M. H. D., Rahman, M. A. (2017). Fourier Transform Infrared (FTIR) Spectroscopy. Membrane Characterization, 3-29. doi: https://doi.org/10.1016/b978-0-444-63776-5.00001-2

[22] Neikov, O. D., Yefimov, N. A. (2019). Powder Characterization and Testing. Handbook of Non-Ferrous Metal Powders, 3-62. doi: https://doi.org/10.1016/b978-0-08-100543-9.00001-4

[23] Yu, Y., Zhao, L., Lin, X., Wang, Y., Feng, Y. (2020). A model to simultaneously evaluate the compressibility and compactibility of a powder based on the compression ratio. International Journal of Pharmaceutics, 577, 119023. doi: https://doi.org/10.1016/ j.ijpharm.2020.119023

[24] Espin, M. J., Ebri, J. M. P., Valverde, J. M. (2019). Tensile strength and compressibility of fine CaCO3 powders. Effect of nanosilica addition. Chemical Engineering Journal, 378, 122166. doi: https://doi.org/10.1016/j.cej.2019.122166

[25] Llusa, M., Faulhammer, E., Biserni, S., Calzolari, V., Lawrence, S., Bresciani, M., Khinast, J. (2014). The effects of powder compressibility, speed of capsule filling and pre-compression on plug densification. International Journal of Pharmaceutics, 471 (1-2), 182-188. doi: https://doi.org/10.1016/j.ijpharm.2014.04.073

[26] Schatt, W., Wieters, K.-P. (1997). Powder Metallurgy - Processing and Materials. EPMA, 492.

[27] German, R. M. (2014). Sintering: From Empirical Observations to Scientific Principles. Butterworth-Heinemann. doi: https:// doi.org/10.1016/c2012-0-00717-x

[28] El-Eskandarany, M. S. (2015). Controlling the powder milling process. Mechanical Alloying, 48-83. doi: https://doi.org/10.1016/ b978-1-4557-7752-5.00003-6

[29] El-Eskandarany, M. S. (2015). Controlling the powder milling process. Mechanical Alloying, 48-83. doi: https://oi.org/10.1016/ b978-1-4557-7752-5.00003-6

[30] Farzadi, A., Solati-Hashjin, M., Bakhshi, F., Aminian, A. (2011). Synthesis and characterization of hydroxyapatite//-tricalcium phosphate nanocomposites using microwave irradiation. Ceramics International, 37 (1), 65-71. doi: https://doi.org/10.1016/ j.ceramint.2010.08.021

How to cite: Puspitasari, P., Iftiharsa, M. A., Zhorifah, H. F. N., Gayatri, R. W. (2021). Analysis of physical properties and compressibility of avian eggshell nanopowders in solid state reaction. EUREKA: Physics and Engineering, 5, 110-120. doi: https://doi.org/ 10.21303/2461-4262.2021.001670 